\title{
The antitumour activity of the interferon inducer bropirimine is partially mediated by endogenous tumour necrosis factor $\alpha$
}

\author{
Marcel Scheringa, Jan N. M. IJzermans, Johannes Jeekel, and Richard L. Marquet \\ Laboratory for Experimental Surgery, Erasmus University, PO Box 1738, 3000 DR Rotterdam, The Netherlands
}

Received 8 June 1990/Accepted 5 September 1990

\begin{abstract}
Summary. Pyrimidinones, like 2-amino-5-bromo-6phenyl-4-pyrimidinone (bropirimine), are potent immunomodulators. Natural killer cell activity and macrophage cytotoxicity are increased after bropirimine treatment, an effect exerted through induction of cytokines. Up to now, the interferons have been supposed to be the main mediators but we have found that tumour necrosis factor $\alpha$ $(\mathrm{TNF} \alpha)$ can also be an important mediator of the bropirimine antitumour effects. Increased serum levels of TNF $\alpha$ were seen in rats after intraperitoneal administration of $200 \mathrm{mg} / \mathrm{kg}$ bropirimine on 2 consecutive days. We also found that the tumour-growth-inhibiting effect of the drug on a colon carcinoma in rats could be reduced about $40 \%$ by giving the rats rabbit anti-TNF $\alpha$ serum just prior to drug treatment. These results indicate that bropirimine can induce the release of TNF $\alpha$ in vivo and that this endogenous TNF $\alpha$ may be important as far as the antitumour effect of the drug is concerned.
\end{abstract}

\section{Introduction}

Immunotherapy is a promising modality in the treatment of cancer. Treatment with cytokines, sometimes in combination with adoptive transfer of immunocompetent cells, is successful in several animal models as well as in patients with different types of malignancies, especially renal cell carcinoma or melanoma $[4,18,21,28,32]$. The cytokines interleukin-2, the interferons, and tumour necrosis factor $\alpha$ (TNF $\alpha$ ) have been most frequently studied. We have been working for some years with interferon $\gamma$ and TNF $\alpha$ in various experimental tumour models $[8,14,15,25]$.

TNF $\alpha$ appeared to have a growth-inhibiting effect in some models [14, 15], but in those models resembling the clinical situation best, i. e. liver metastases of colon carcinoma, a significant growth inhibition could not be demon-

Offprint requests to: $\mathrm{M}$. Scheringa strated despite the use of different administration schedules [25]. Therefore we, and others, concluded that TNFo should be used in combination therapy, for example with other biological response modifiers, and it has indeed been demonstrated that combining TNF $\alpha$ with interferon $\gamma$ or $\alpha$ results in synergistic antitumour effects $[1,3,27,39]$.

Another suggested possibility of increasing the efficacy of exogenous TNF $\alpha$, is to administer it at the time that endogenous TNF $\alpha$ is released. This therapy has been referred to as endogenous-exogenous therapy [9]. Examples of TNF $\alpha$-inducing agents are endotoxin (lipopolysaccharide) and OK432. The former is a strong TNF $\alpha$ inducer but can hardly be used clinically because of severe toxicity, while the latter is a strong and far less toxic TNF $\alpha$ inducer $[10,26]$.

In search for other TNF $\alpha$-inducing agents, the known interferon inducer bropirimine was tested in vivo. We examined whether it can cause TNF $\alpha$ release by measuring serum levels of TNF $\alpha$ after intraperitoneal (i.p.) administration of bropirimine in rats. Furthermore, we examined the effect of bropirimine treatment on a colon carcinoma and a rhabdomyosarcoma as compared to TNF $\alpha$ treatment. Finally, we examined whether the antitumour effect of bropirimine could be blocked by pretreatment with rabbit anti-TNF $\alpha$ serum.

\section{Materials and methods}

Animals. Male rats of the inbred WAG $\left(\mathrm{RT}^{\mathrm{L}}\right)$ strain were obtained from Harlan-CPB (Austerlitz, The Netherlands). The animals were bred under specific-pathogen-free conditions and were $10-14$ weeks old when used.

Tumours. A 1,2-dimethylhydrazine-induced, moderately differentiated colon adenocarcinoma (CC531) and a rhabdomysarcoma (R2K), transplantable in syngeneic WAG rats, were used $[13,19]$. CC531 was maintained in vitro in RPMI- 1640 medium supplemented with $5 \%$ fetal calf serum and R2K in Dulbecco's modified Eagle medium with $10 \%$ newborn calf serum (sera were screened for virus and Mycoplasma infections). The media were supplemented with $1 \%$ penicillin $(5000 \mathrm{IU} / \mathrm{ml})$, $1 \%$ streptomycin $(5000 \mu \mathrm{g} / \mathrm{ml})$ and $1 \% \mathrm{~L}$-glutamine $(200 \mathrm{mM})$, all obtained from Gibco (Paisley, UK). Before use, the cells were trypsinized 


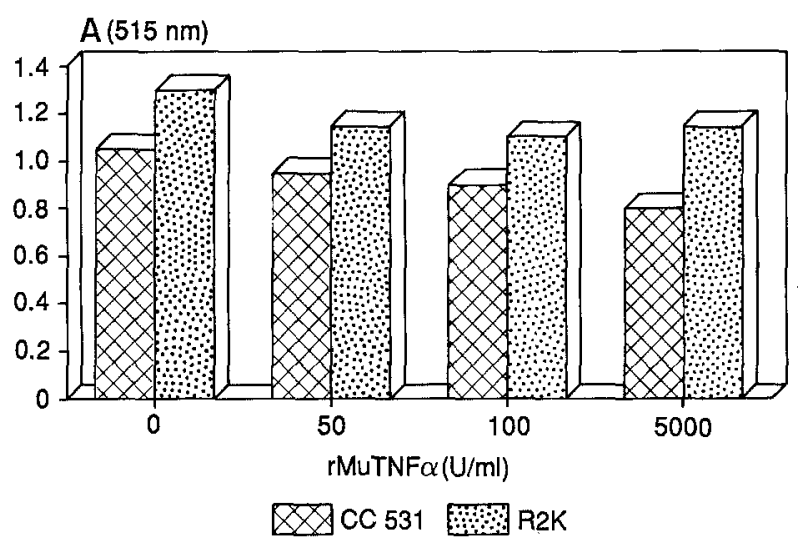

Fig. 1. Effect of different concentrations of recombinant murine tumour necrosis factor $\alpha(r M u T N F \alpha)(\mathrm{U} / \mathrm{ml})$ on in vitro growth of tumour cell lines CC531 and R2K after incubation for $48 \mathrm{~h}$. Viability was measured using the MTT assay; absorbance $(A)$ was measured at $515 \mathrm{~nm}$

$\left(5 \mathrm{~min}, 37^{\circ} \mathrm{C}\right.$ ), centrifuged $(5 \mathrm{~min}, 700 \mathrm{~g}$ ), resuspended in their media and counted. Viability was measured using Trypan blue $(0.3 \%$ in a $0.9 \%$ $\mathrm{NACl}$ solution); it consistently exceeded $95 \%$.

In vitro testing of tumour cell lines for response to TNF. Tumour cells were seeded at $1 \times 10^{4}$ cells/well in flat-bottomed 96-well microtiter plates (Costar, Cambridge, Mass.) in a final volume of $0.2 \mathrm{ml} \mathrm{me-}$ dium/well, and incubated at $37^{\circ} \mathrm{C}$ in $5 \% \mathrm{CO}_{2}$ for $48 \mathrm{~h}$ in the presence of different concentrations of recombinant murine tumour necrosis factor $\alpha$ (rMuTNF $\alpha$ ). Concentrations of rMuTNF $\alpha$ were $0 \mathrm{U} / \mathrm{ml}, 50 \mathrm{U} / \mathrm{ml}$, $100 \mathrm{U} / \mathrm{ml}$ and $5000 \mathrm{U} / \mathrm{ml}$. Growth of tumour cells was measured using an MTT (3-4,5-dimethyl-thiazol-2-yl)-2,5-diphenyl tetrazoliumbromide assay (for details see [25]). Absorbance was read at $515 \mathrm{~nm}$ using a Flow Titertek Multiskan (McLean, Va.) plate reader. Eight replicate wells were used for each concentration tested.

Agents. rMuTNF $\alpha$ was kindly provided by Dr. W. Fiers (Lab. Molecular Biology, Gent, Belgium). The preparation was over $99 \%$ pure, containing less than $4 \mathrm{ng}$ endotoxin/mg protein. 2-Amino-5-bromo-6-phenyl-4pyrimidinone (bropirimine) was produced as reported previously [31] and provided by the Upjohn Company, Kalamazoo, Mich., USA.

Rabbit anti-(mouse-recombinant TNF $\alpha$ ) serum (RaTNFS) was prepared in our laboratory. Rabbits were three-times immunized with rMuTNFo in combination with Freund's adjuvants (25 $\mu \mathrm{g}$ rMuTNF $\alpha$ /immunization, administered intracutaneously). Blood was collected 1 week after the last immunization, serum was stored and tested for anti-TNF $\alpha$ activity. RaTNFS had a neutralizing capacity of $100000 \mathrm{U} / \mathrm{ml}$ serum in the L929 bioassay (see next paragraph). In vivo $0.5 \mathrm{ml}$ RaTNFS given intravenously (i.v.) protected rats against the lethal effect of $20 \mu \mathrm{g}$ rMuTNF $\alpha$ given subsequently. Rats not pretreated with RaTNFS ( $n=2)$ both died while pretreated rats $(n=2)$ survived after rMUTNF $\alpha$ administration without signs of toxicity.

TNF $\alpha$ assay. For measurement of TNF $\alpha$ in the serum samples of the rats a standard cytotoxicity assay for TNFo, using the L929 cell line, was performed. Cells were seeded at $5 \times 10^{5}$ cells/well $(100 \mu \mathrm{l})$ in flat-bottomed 96-well microtiter plates in the presence of actinomycin-D (final concentration $1 \mu \mathrm{g} / \mathrm{ml}$ ). Sera, 50 and 100 times diluted, were added (to a final volume of $200 \mu \mathrm{l}$ ) and after $20 \mathrm{~h}$ the cell survival was estimated by the colorimetric MTT assay. Absorbance was read at $515 \mathrm{~nm}$. The TNF $\alpha$ concentrations were calculated by comparison with a standard curve.

Experimental design. To test the sensitivity of CC531 and R2K for TNF $\alpha$ and bropirimine in vivo, a sub-renal-capsule assay $[13,25]$ was performed. In summary, a piece of tumour of about $10 \mathrm{mg}$ is placed underneath the renal capsule of the rats, whereafter treatment is started. After 1 week animals are sacrificed, tumours enucleated and subsequently weighed.

Treatment consisted of i.v. injections of $4 \mu \mathrm{g} / \mathrm{kg}$ rMuTNF $\alpha$ (rMuTNFo treatment) on days 0,2 and 4 or i. p. injections of $200 \mathrm{mg} / \mathrm{kg}$ of bropirimine (bropirimine/treatment) on days 0 and 1 . Control animals
Table 1. Sensitivity of CC531 and R2K for rMuTNFa or bropiriminea

\begin{tabular}{lcrl}
\hline Treatment & $\begin{array}{l}\text { Mean tumour } n \\
\text { weight (mg) } \\
\pm \mathrm{SD}\end{array}$ & Tumour weight (mg) \\
\hline Tumour CC531 & & & \\
Control & $13 \pm 3$ & 12 & $8,9,10,11,12,13,14,16,16,16,17,19$ \\
rMuTNFo & $7 \pm 3$ & 12 & $2,4,6,7,7,7,7,8,9,9,11,12$ \\
Control & $27 \pm 11$ & 10 & $10,18,22,22,24,24,26,32,35,52$ \\
Bropirimine* & $10 \pm 5$ & 8 & $3,5,8,12,12,12,14,17$ \\
Tumour R2K & & & \\
Control & $26 \pm 10$ & 10 & $11,13,21,22,24,26,30,35,40,41$ \\
rMuTNF $\alpha$ & $24 \pm 9$ & 10 & $11,14,17,18,26,28,29,32,33,37$ \\
Control & $20 \pm 5$ & 12 & $11,14,15,17,17,19,21,22,24,25,26,28$ \\
Bropirimine* & $12 \pm 6$ & 10 & $5,6,6,11,11,12,14,15,16,24$ \\
\hline
\end{tabular}

a In vivo sensitivity of tumours CC531 and R2K for rMuTNFo and bropirimine. A sub-renal-capsule assay was performed in rats. Control rats received i.v. $1 \mathrm{ml} \mathrm{HBSS}$ on days 0,2 and 4 and $1 \mathrm{ml}$ phosphatebuffered saline i.p. on days 0 and 1 after tumour implantation. rMuTNF $\alpha$-treated rats received i. v. $4 \mu \mathrm{g}$ rMuTNF $\alpha$ on days 0,2 and 4 ; bropirimine-treated rats received i. p. $200 \mathrm{mg} / \mathrm{kg}$ bropirimine on days 0 and 1 after tumour implantation. Animals were sacrificed at day 7 and tumours were enucleated and weighed. Both $\mathrm{rMuTNF} \alpha$ and bropirimine had a significant growth-inhibiting effect on tumour CC531 $(P<0.01$ and $P<0.05$ respectively). Growth of tumour $\mathrm{R} 2 \mathrm{~K}$ was significantly inhibited by bropirimine $(P<0.01)$ but rMuTNF $\alpha$ did not inhibit growth of $\mathrm{R} 2 \mathrm{~K}$ * Significantly different from control

received Hanks balanced salt solution (HBSS) i.v. and phosphatebuffered saline i.p. (control treatment). Each treatment was tested twice on both tumours.

In order to study the TNF $\alpha$-inducing capacity of bropirimine, rats received $200 \mathrm{mg} / \mathrm{kg}$ of the drug i. p. on 2 consecutive days (the therapeutic regimen). During the second day blood samples were collected and serum was stored at $-20^{\circ} \mathrm{C}$. Blood samples were taken $5 \mathrm{~min}$ prior to the second bropirimine administration and after 1,2,3,4 and $6 \mathrm{~h}$. Control animals received HBSS i.p.

In another series of experiments, using the sub-renal-capsule assay model, we tested whether the antitumour effect of bropirimine against an in vivo proven TNF-sensitive tumour (CC531) could be blocked by pretreatment with $0.25 \mathrm{ml}$ RaTNFS i.v. On days 0 and 1 the rats received $200 \mathrm{mg} / \mathrm{kg}$ bropirimine i.p. immediately after an i.v. injection of 0.25 HBSS, normal rabbit serum or RaTNFS.

Statistical analysis. For measurement of significance of difference in the sub-renal-capsul assay, the Wilcoxon's rank sum test was performed. For measurement of significance between control and bropirimine-treated groups in the TNFo-inducing experiments, Student's $t$-test was used for the various time points.

\section{Results}

\section{In vitro sensitivity of CC531 and $R 2 K$ for $r M U T N F \alpha$}

Both cell lines were relatively insensitive to the cytostatic/cytolytic activity of rMuTNF $\alpha$ as measured after $48 \mathrm{~h}$ incubation (Fig. 1). rMuTNF $\alpha$ caused only a minor, though significant, reduction in the number of viable cells in both cell lines at a concentration of $5000 \mathrm{U}$ $\mathrm{rMuTNF} \alpha / \mathrm{ml}$.

\section{In vivo sensitivity of $C C 531$ and $R 2 K$ for $r M U T N F \alpha$ or bropirimine}

RMuTNF $\alpha$ as well as bropirimine did have a significant growth-inhibiting effect on tumour CC531, while only 


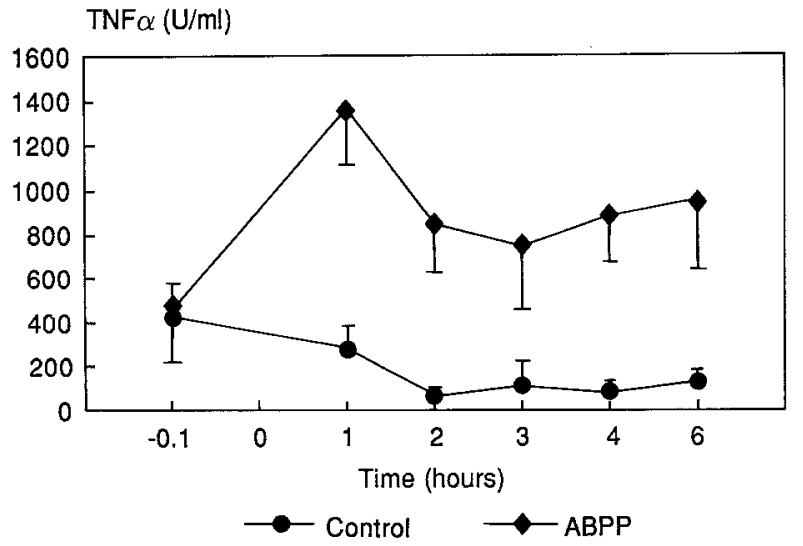

Fig. 2. Serum TNF $\alpha$ levels in rats after treatment with bropirimine ( $200 \mathrm{mg} / \mathrm{kg}$ i.p. on 2 consecutive days) or after treatment with Hanks balanced salts solution (HBSS; $1 \mathrm{ml}$ i. p. on 2 consecutive days) \pm SEM. Samples were taken $5 \mathrm{~min}$ prior to the second administration and $1,2,3$, 4 and $6 \mathrm{~h}$ thereafter. TNF $\alpha$ was measured using the L929 bioassay. At 1 , $2,3,4$ and $6 \mathrm{~h}$. TNF $\alpha$ serum levels were significantly increased $(P<0.005$ for each time point) in the bropirimine-treated group as compared to HBSS controls

bropirimine could inhibit growth of tumour R2K. Agents were tested twice on each tumour (Table 1; results of one of the experiments is shown). Efficacy for both agents was of the same order of magnitude for colon cancer CC531.

\section{In vivo TNF $\alpha$ induction by bropirimine}

Administration of $200 \mathrm{mg}$ bropirimine $/ \mathrm{kg}$ i. p. on 2 consecutive days (the therapeutic regimen) resulted in a significant increase in TNF $\alpha$ serum levels. TNF $\alpha$ serum levels peaked $1 \mathrm{~h}$ after the second administration and remained significantly elevated for up to $6 \mathrm{~h}$ at least. Mean TNF $\alpha$ serum levels in controls were surprisingly high at $5 \mathrm{~min}$ because two of the control rats had unexplained high TNF $\alpha$ starting levels.

\section{Blocking of the antitumour effect of bropirimine against CC531 in vivo by RaTNFS}

In two experiments RaTNFS partially blocked the tumourgrowth-inhibiting effect of bropirimine on CC531 (Table 2 ). In the first experiment, the effect of bropirimine + RaTNFS was $59 \%$ of the effect of bropirimine + HBSS, while in the second experiment the effect of bropirimine + RaTNFS was $57 \%$ of the effect of bropirimine + normal rabbit serum.

\section{Discussion}

Although it has been described how bropirimine induces the release of lymphokines other than interferon [20], its TNF $\alpha$-inducing capacity has never been emphasized before. This capacity could be very interesting in the light of its role in tumour therapy. So far, the antitumour effects of bropirimine were believed to be especially mediated by
Table 2. Blocking of the antitumour effect of bropirimine on colon cancer CC531 by pretreatment with rabbit anti-(mouse recombinant TNF $\alpha$ ) serum (RaTNFS) ${ }^{\mathrm{a}}$

\begin{tabular}{|c|c|c|c|}
\hline $\begin{array}{l}\text { Pretreatment/ } \\
\text { treatment }\end{array}$ & $\begin{array}{l}\text { Mean tumour } \\
\text { growth (mg) } \\
\pm \mathrm{SD}\end{array}$ & $n$ & Tumour growth (mg) \\
\hline \multicolumn{4}{|l|}{ Experiment 1} \\
\hline Control/control & $25 \pm 1$ & 12 & $\begin{array}{l}2,13,18,25,25,25,26,26,27, \\
31,31,51\end{array}$ \\
\hline Control/bropirimine* & $4 \pm 2$ & 10 & $0,1,3,4,5,5,5,6,6,6$ \\
\hline RaTNFS/bropirimine** & $13 \pm 8$ & 12 & $\begin{array}{l}0,0,1,9,13,13,14,18,19,21, \\
22,22\end{array}$ \\
\hline \multicolumn{4}{|l|}{ Experiment 2} \\
\hline Control/control & $13 \pm 5$ & 12 & $\begin{array}{l}5,7,7,7,10,14,14,14,17,17 \\
20,20\end{array}$ \\
\hline NRS/bropirimine* & $3 \pm 4$ & 6 & $-2,-1,1,5,5,7$ \\
\hline RaTNFS/bropirimine**** & $7 \pm 5$ & 8 & $1,2,2,4,11,11,12,12$ \\
\hline
\end{tabular}

a In two separate experiments the effect of pretreatment with RaTNFS on the antitumour effect of bropirimine on tumor CC531 in a sub-renalcapsule assay was measured. Animals were pretreated with HBSS (control), normal rabbit serum (NRS) or rabbit anti-TNF $\alpha$ serum $(0.5 \mathrm{ml}$ i. v. just prior to treatment), and then treated with HBSS (control, $1 \mathrm{ml}$ i. p.) or bropirimine $(200 \mathrm{mg} / \mathrm{kg}$ i.p.) at days 0 and 1 after tumour implantation. After 7 days animals were sacrificed, tumours were enucleated and weighed and tumour growth was calculated. In both experiments, groups treated with bropirimine, regardless of pretreatment, were significantly different from the HBSS-treated groups $(P<0.01)$. In both experiments the groups pretreated with HBSS or NRS and subsequently treated with bropirimine were significantly different from the groups pretreated with RaTNFS and treated with bropirimine $(P<0.01)$

* Significantly different from control/control

** Significantly different from control/control and from control/bropirimine

*** Significantly different from control/control and from NRS/bropirimine

endogenous interferons, leading to increased natural killer (NK) cell and macrophage cytotoxicity [5, 12]. The results of this study suggest that endogenous TNF $\alpha$ can also be an important effector of bropirimine activity. In rats, $200 \mathrm{mg} / \mathrm{kg}$ bropirimine, given i.p. on 2 consecutive days, resulted in increased serum levels of TNF $\alpha$. All rats in the bropirimine-treated group had high starting levels of serum $T N F \alpha$, indicating that single bropirimine administration does also induce TNF release (TNF $\alpha$ serum levels were only measured after the second bropirimine administration). The high mean TNF $\alpha$ serum levels in the control group at $5 \mathrm{~min}$ were due to two of the control animals. These animals had persistently higher TNF $\alpha$ levels throughout the experiment than the other rats in the control group, in whose serum virtually no TNF $\alpha$ could be demonstrated. The tumour-growth-inhibiting effect of bropirimine against an in vivo proven $\mathrm{TNF} \alpha$ sensitive tumour, could be reduced about $40 \%$ by pretreatment with rabbit anti-TNF $\alpha$ serum. This study shows that TNF $\alpha$ is only one of the mediators through which bropirimine exerts its antitumour effect, since the in vivo TNF $\alpha$-insensitive tumour $\mathrm{R} 2 \mathrm{~K}$ responded as well to bropirimine as did tumour CC531. Bropirimine has already been shown to be a potent immunotherapeutic agent against different types of experimental cancer $[5,16,17]$, which is confirmed by this study. Treatment with bropirimine often resulted not only in 
growth inhibition but even in tumour regression. Earlier observations in our laboratory have shown that bropirimine does not only inhibit growth of tumour CC531 in a subrenal-capsule assay but also in an artificial liver metastases model [6].

The TNFo-inducing capacity of bropirimine is the more interesting with regard to the so-called endogenousexogenous therapy. This therapy seems to have better antitumour efficacy than either induction of endogenous TNF $\alpha$ or administration of exogenous TNF $\alpha$ [9]. So far, endogenous-exogenous therapy has been performed using the streptococcal preparation OK432 as the TNF $\alpha$-inducing agent [26]. Like bropirimine, OK432 causes the release of TNF $\alpha$ [23] and it increases macrophage [23], NK cell, [33] and large granular lymphocyte cytotoxicity [29]. It also induces the release of interferon [22]. Peak levels of TNF $\alpha$ in serum of mice after OK432 treatment [24] were in the same order as peak levels of TNFo in serum of rats after bropirimine treatment in this study. Although comparison of results obtained in rats or mice can never lead to final conclusions, bropirimine might well be an alternative to OK432 in endogenous-exogenous therapy. It has already been reported that bropirimine and TNF $\alpha$ have synergistic antitumour effects [13].

This study emphasizes again that in vitro findings, as far as biological response modifiers are concerned, do not predict the in vivo outcome. Both tumours CC531 and $\mathrm{R} 2 \mathrm{~K}$ were in vitro relatively insensitive to the cytostatic/cytolytic activity of rMuTNFo, but growth of tumour CC531 was strongly inhibited in vivo by treatment with rMuTNF $\alpha$.

The recognition of bropirimine as being a TNF $\alpha$ inducer in vivo may well explain a previously reported effect of the drug that could not be explained on the basis of its interferon-inducing capacity. It appeared that bropirimine could protect mice against listeriosis [2]. This protecting effect of the drug against an infection with Listeria monocytogenes, remained when the mice were pretreated with a potent anti-interferon antibody, indicating that this effect was not due to endogenous interferon. It is known that endogenous TNF $\alpha$ protects mice against infection with Listeria, especially in the early stages of the infection $[7,11]$, so the protecting effect of bropirimine could well be mediated by endogenous TNF $\alpha$.

From the results presented in this study it can be concluded that bropirimine can induce the release of TNF $\alpha$ in rats; this endogenous TNF $\alpha$ can be important as far as the antitumour effects of bropirimine are concerned and could make the drug an even more important, immunomodulatory, antitumor agent.

\section{References}

1. Agah R, Malloy B, Sherrod A, Mazumder A (1988) Successful therapy of natural killer-resistant pulmonary metastases by the synergism of gamma-interferon with tumor necrosis factor and interleukin-2 in mice. Cancer Res 48: 2245

2. Anthony LS, Stenvenson MM, Skamene E (1984) Enhancement of resistance to Listeria monocytogenes infection in mice by pyrimidine analogs. Clin Invest Med 7: 343
3. Balkwill FR, Lee A, Aldam G, Moodie E, Thomas JA, Tavernier J, Fiers W (1986) Human tumor xenografts treated with recombinant human tumor necrosis factor alone or in combination with interferons. Cancer Res 46: 3990

4. Borden EC, Balkwill FR (1984) Preclinical and clinical studies of interferons and interferon inducers in breast cancer. Cancer 53: 783

5. Eggermont AMM, Marquet RL, de Bruin RWF, Weimar W, Jeekel J (1986) Site-specific anti-tumour effects of 2 pyrimidinone compounds in rats. Br J Cancer 54: 337

6. Eggermont AMM, Marquet RL, de Bruin RWF, Jeekel J (1986) Effects of the interferon-inducer ABPP on colon cancer in rats: importance of tumor load and tumor site. Cancer Immunol Immunother 22: 217

7. Havell EA (1987) Production of tumor necrosis factor during murine listeriosis. J Immunol 139: 4225

8. IJzermans JNM, Marquet RL, Bouwman E, de Bruin RWF, van der Meide PH, Jeekel J (1987) Succesful treatment of colon cancer in rats with recombinant interferon gamma. Br J Cancer 56: 795

9. Inagawa H, Oshima H, Soma G, Mizuno D (1988) TNF induces endogenous TNF in vivo: the basis of EET therapy as a combination of rTNF together with endogenous TNF. J Biol Response Modif 7: 596

10. Kato M, Kakehi, Soma G, Gatanaga T, Mizuno D (1985) Antitumour therapy by induction of endogenous tumour necrosis factor. Lancet 3: 270

11. Kratz SS, Kurlander RJ (1988) Characterization of the pattern of inflammatory cell influx and cytokine production during the murine host defense to Listeria monocytogenes. J Immunol 141: 598

12. Lotzova E, Saqvary CA, Khan A, Stringfellow DA (1984) Stimulation of natural killer cells in two random-bred strains of athymic rats by interferon-inducing pyrimidinone. J Immunol 132: 2566

13. Marquet RL, Westbroek DL, Jeekel J (1984) Interferon treatment of a transplantable colon adenocarcinoma; importance of tumor site. Int J Cancer 33: 689

14. Marquet RL, IJzermans JNM, de Bruin RWF, Fiers W, Jeekel J (1987) Anti-tumor activity of mouse tumor necrosis factor (TNF) on colon cancer in rats is promoted by recombinant rat interferon gamma, toxicity is reduced by indomethacin. Int J Cancer 40: 550

15. Marquet RL, Eggermont AMM, de Bruin RWF, Fiers W, Jeekel J (1988) Combined treatment of colon adenocarcinoma in rats with TNF and the interferon inducer ABPP. J Interferon Res 8: 319

16. Milas L, Hersh EM, Stringfellow DA, Hunter N (1982) Studies on the antitumor activities of pyrimidinone-interferon inducers. Effect against artificial and spontaneous lung metastases of murine tumors. JNCI 68: 139

17. Oku T, Imanishi J, Kishida $T$ (1984) Interferon counteracts pyrimidinone-induced hyporeactivity and the combined treatment has antitumor effect in mice. Gann 75: 631

18. Pfreundschuh MG, Tilman Steinmetz H, Tueschen R, Schenk V, Diehl V, Schaadt M (1989) Phase 1 study of intratumoral application of recombinant human tumor necrosis factor. Eur $\mathrm{J}$ Cancer Clin Oncol 25: 379

19. Reinhold HS (1966) Quantitative evaluation of the radiosensitivity of cells of a transplantable rhabdomyosarcoma in the rat. Eur J Cancer 2: 33

20. Richard KA, Mortensen RF, Tracey DE (1987) Cytokines involved in the augmentation of murine natural killer activity by pyrimidinones in vivo. J Biol Response Modif 6: 647

21. Rosenberg SA (1988) Immunotherapy of cancer using interleukin 2 : current status and future prospects. Immunol Today 9:58

22. Saito M, Ebina T, Koi M, Yamaguchi T, Kawade Y, Ishida N (1982) Induction of interferon-gamma in mouse spleen cells by OK-432, a preparation of Streptococcus pyogenes. Cell Immunol 68: 187

23. Saito M, Nanjo M, Aonuma E, Noda T, Nakadate I, Ebina T, Ishida N (1984) Activated macrophages are responsible for the tumor-inhibitory effect in mice receiving intravenous injection of $\mathrm{OK}-432$. Int J Cancer 33: 271

24. Satoh M, Inagawa H, Shimada Y, Soma G, Oshima H, Mizuno D (1987) Endogenous production of tumor necrosis factor in normal mice and human cancer patients by interferons and other cytokines combined with biological response modifiers of bacterial origin. J Biol Response Modif 6: 512 
25. Scheringa M, Jeekel J, Marquet RL (1989) Anti-tumor effect of recombinant murine TNF-alpha (rMuTNFa) given by continuous infusion as compared to repeated $i$. $v$. injections in a rat liver metastasis model. Int $\mathrm{J}$ Cancer 43: 905

26. Sekimoto M, Kokunai I, Shimano T, Kobayshi T, Takeda T, Haruna $\mathrm{N}$, Yamamoto A, Mori T (1988) Production of tumor necrosis factor (TNF) by monocytes from cancer patients and healthy subjects induced by OK-432 in vitro, and its augmentation by human interferon gamma. J Clin Lab Immunol 27: 115

27. Shah P, van der Meider PH, Borman T, Schroeder N, Bliss JM, Coombes RC (1989) Effect of human recombinant tumour necrosis factor and rat gamma interferon on nitrosomethylurea-induced mammary tumours. Br J Cancer 59: 206

28. Talmadge JE, Black PL, Tribble H, Pennington R, Bowersox O, Schneider M, Phillips H (1987) Preclinical approaches to the treatment of metastatic disease: therapeutic properties of RH TNF, RM IFN-gamma, and RH IL-2. Drugs Exp Clin Res 8: 3327

29. Uchida A, Micksche M, Hoshino T (1984) Intrapleural administration of OK432 in cancer patients: augmentation of autologous tumor killing activity of tumor-associated large granular lymphocytes. Cancer Immunol Immunother 18: 5

30. Watanabe N, Niitsu Y, Yamauchi N, Umeno H, Sone H, Neda H, Urushizaki I (1988) Antitumor synergism between recombinant human tumor necrosis factor and recombinant human interferon-r. J Biol Response Modif 7: 24

31. Wierenga W, Skulnick HI, Stringfellow DA, Weed SD, Renis HE, Eidson EE (1980) 5-Substituted 2-amino-6-phenyl-4(3H)-pyrimidinones. Antiviral and interferon inducing agents. J Med Chem 23: 237

32. Winkelhake JL, Stampfl S, Zimmerman RJ (1987) Synergistic effects of combination therapy with human recombinant interleukin-2 and tumor necrosis factor in murine tumor models. Cancer Res 47 3948

33. Yamaue H, Katsumi M, Tabuse K, Tabuse Y, Kuribayashi K, Nishihara T, Saito K (1987) Induction of activated natural killer cells from murine spleen cells primed in vivo and subsequently challenged in vitro with the streptococcal preparation OK 432. Cancer Immunol Immunother 25: 169 